\title{
Preliminary Study on the Biodegradability of Chitosan Films Emulsified with Palm Oils (Aracaceae) from the Brazilian Cerrado
}

\author{
Arlete Barbosa dos Reis ${ }^{1,2, *}$ and Sônia Ribeiro Arrudas ${ }^{3,4}$ \\ ${ }^{1}$ Federal University of the Jequitinhonha and Mucuri Valleys, Campus JK, Diamantina, Minas Gerais, Brazil \\ ${ }^{2}$ Institute of Science and Technology - Chemical Engineering Course, Brazil \\ ${ }^{3}$ State University of Montes Claros, Montes Claros, Minas Gerais, Brazil \\ ${ }^{4}$ Center of Biological Sciences and Health, Brazil
}

\begin{abstract}
Non-toxic products with distinguishable characteristics are desirable for use in the packaging sector. Biopolymers fit this criterion and can serve as vehicles for the addition of various compounds, such as enzymes, dyes, antioxidant agents, or monounsaturated fatty acids, to provide useful qualities to a product, such as biodegradability. A biopolymer obtained from fishing industry waste residues can be combined with fatty acids to form films and emulsions with different characteristics to be used in different drug production, packaging, and product protection. This study aimed to use a natural biopolymer, chitosan, in combination with oils from the Mauritia flexuosa L.f., ("buriti") and Acrocomia aculeata ("macaúba") species of palm trees to develop films that exhibit excellent biodegradability in soil. The degradation of chitosan films (CF), emulsified chitosan films with buriti oil (CFB), and emulsified chitosan films with macaúba oil (CFM) in soil was investigated, where the CFB samples showed the best protection against moisture and the largest weight reduction over 30,60 , and 90 day testing periods. Further studies are needed to test the practical application of these films, but the results of the CFB sample indicate that these chitosan films imbued with natural oils from the Mauritia flexuosa L.f. and Acrocomia aculeata species have great potential for use in the packaging sector.
\end{abstract}

Keywords: Biopolymer, Soil, Palm oil, Packaging, Mauritia flexuosa L.f., Acrocomia aculeata.

\section{INTRODUCTION}

Among the various damages inflicted upon the environment, all of which arise from humans, one concerns the plastic waste of fossil fuels. These residues take a long time to spontaneously degrade, and given this long, useful life of plastics, short-term experimental methods to predict degradation paths require further study [1]. As the population increases each year, these solid waste management issues increase as well [2]. Inadequate management of urban solid waste in terms of treatment, recycling, final disposal, and management strategies can cause ecological disasters that present a threat to public health and natural resources [3].

Kaza et al. (2018) [4] reported that the world population generated 242 million tons of plastic waste in 2016, and it is believed that by 2050 plastic production will increase four-fold [5]. Furthermore, plastic waste shortens the life expectancy of animals that consume it and contaminates bodies of water when it is dumped into channels and oceans [6]. This is based on their increased production as well as their lack of degradability, which drew the world's attention to the problem of pollution [7].

*Address correspondence to this author at the Federal University of the Jequitinhonha and Mucuri Valleys, Campus JK, Diamantina, Minas Gerais, Brazil; Tel: 55-38-999662212; Fax: 55-38-35321200;

E-mail: arlete.reis@ict.ufvjm.edu.br
Consequently, numerous investigations into biodegradable plastic waste have been conducted in recent years [8]. Plastic materials participate in waste generation from their industrial production to their arrival at the consumer [9]. The public demand for ecological and sustainable processes, alongside the growing limitation of fossil fuels, has resulted in the formation of a market for bio-based plastics [10]. This has led to research aimed at replacing plastic with other materials and evaluating the duration of these substitute residues [11]. Furthermore, innovative technologies have been developed for producing biodegradable polymers [12-16].

Chitin, a polysaccharide of animal origin, can be obtained from fishing industry waste. This compound can be deacetylated in chitosan, a non-toxic, biocompatible, and biodegradable biopolymer, or it can be hydrolysed into $\mathrm{N}$-diacetylquitobiosis and $\mathrm{N}$ acetylglycosamine oligomers by micro-aerobic and anaerobic organisms [17]. The chitosan has various applications, including as a supporting agent in drugs or as a vehicle for additive addition, making it suitable for the packaging sector [18]. Therefore, expanding the knowledge of chitosan biopolymer degradation rates would be greatly beneficial, considering its applicability in many areas. [19] stated that chitosan biopolymers in the packaging sector are employed as polymeric matrix coatings or in primary packaging. 
In this context, the present study aims to study the degradation of chitosan films in samples of common soil collected from the garden of the Federal University of Vales of the Jequitinhonha and Mucuri Valleys (UFVJM), Campus JK (Diamantina, Minas Gerais, Brazil). Chitosan film samples with and without the addition of oils extracted from the Mauritia flexuosa L.f. and Acrocomia aculeata species were buried in the soil and collected after 30,60, and 90 days. After each collection, the solubility, moisture content, and weight loss of the chitosan films with and without the oil addition were analysed.

The most important sources of chitin are crab shells, shrimp, and other arthropods. According to [2023], chitin and chitosan are distinguishable by their varying degrees of deacetylation, chitosan being the completely deacetylated form of the polymer [24]. In an aqueous solution, the chitosan biopolymer provides a positively charged macro ion and is therefore also known as soluble chitin. In nature, the polymer is partially acetylated and describes a wide range of polymers with various proportions of D-glucosamine and $\mathrm{N}$-acetyl-D-glucosamine residues. Furthermore, it is decomposable and exhibits good film membrane formation and biocompatibility functions [25-27]. As a result of its versatility, the chitosan biopolymer can act as a vehicle for inserting various additives, including oils extracted from natural sources. Some examples of these oils are Mauritia flexuosa L.f. ("buriti") and Acrocomia aculeata ("macaúba"), which are species of the Arecaceae family that are rich in monounsaturated fatty acids and found in the Brazilian Cerrado.

Buriti is a palm of the Arecaceae family found throughout the Brazilian territory, predominantly in the biomes of the Amazon and Brazilian Cerrado [28-29], and is an extremely versatile plant that is classified as a functional food for both animals and humans due to its nutritional composition [30]. In folk medicine, the fruit of buriti is used as a flu treatment and for vitamin A deficiencies [31-33]. This leads us to believe that buriti contains antioxidants. Furthermore, since its composition is rich in phenolic compounds [29], the enzyme polyphenol oxidase could be extracted [34]. Therefore, it is essential to further investigate the biological activities of buriti pulp and oil [35] and their potential as sources for new bioactive compounds [36], [30]. Buriti oil is rich in monounsaturated fatty acids and is similar to commercial oilseeds, such as olive, canola, and peanut oils [30]. Due to its phenolic composition, buriti oil has gained interest for its healing and photoprotective properties, as well as its use as an antioxidant or natural antimicrobial [37]. Besides, materials produced with buriti oil have an improved plasticizing effect and a greater susceptibility to soil degradation [38], characteristics that would benefit applications in the packaging sector.

Macaúba arborescent, is part of the Arecaceae family and reaches over 16 meters in height. They are typically found in the tropical and subtropical regions of the Americas and the Brazilian Cerrado [39-41]. This species is also known for being an oil palm of high economic value due to its high productivity and the various uses of its different components [42], giving it the potential for energetic, socio-environmental, and oil applications. Its energy application is demonstrated in briquette production [42], and its socio-environmental applications include serving as a raw material for food, pharmaceutical, cosmetic, and biofuel production [4344]. Given the lipid-rich composition of both its pulp and almond [45-48], as well as its employment in light biodiesel production, it is also suitable as an aviation fuel component [49]. Mesocarp oil is characterised by a high content of carotenoids and oleic acid, while pulp oil only contains approximately $40 \%$ lauric acid [50]. It mainly contains unsaturated triacylglycerols, which are composed of long-chain fatty acids; in fact, high proportions of triacylglycerols saturated with mediumchain fatty acids are observed in the pulp [51-53]. The oil extracted from the pulp of macaúba fruits has greater thermal stability than the oil extracted from the seed [54]. This helps maintain its intrinsic oxidative stability to allow for high-quality pulp oil to be acquired for industrial purposes [55].

All areas of industry strive to develop durable materials that are resistant to use that are also biodegradable [15]. This is difficult to achieve, but considering the investments of bioplastic companies [10] and the negative environmental impact of nonbiodegradable plastics and waste generation [56], biodegradable polymers are a promising prospect. Besides developing new environmentally friendly materials, reusing waste to obtain these new materials is another major industrial process.

As chitosan is extracted from a bio-waste product, it has a lower cost than that of other biopolymers [57]. Therefore, it can overcome some of the disadvantages of the original polymers when employed as an alternative in the packaging industry [58]. Finally, the environmental concerns regarding the entire production process of chitosan-based films, from raw material extraction to the lifetime of the residue after disposal, are also discussed to find more ecological alternatives 
[22]. because of this, this work aimed at the development and evaluation of the biodegradability of chitosan films incorporated with vegetable oils.

\section{MATERIAL AND METHODS}

\section{Materials}

Quitosana, with $98.15 \%$ deacetylation degree, was acquired from Polymar Indústria, Comércio, Importação e Exportação Ltda, Glacial acetic acid $\left[\mathrm{C}_{2} \mathrm{H}_{4} \mathrm{O}_{2}\right]$. P.A. was acquired by Synth (Diadema, Brazil). Chitosan and acetic acid were obtained and used without further purification. The buriti oil (Mauritia flexuosa L.f.) was provided by Family Farmers and Agroextractivists Grande Sertão Ltda (Minas Gerais, Brazil; $15^{\circ} 26^{\prime} 10^{\prime \prime S}$, $44^{\circ} 40^{\prime} 44^{\prime \prime} \mathrm{W}$ ). The macaúba fruits (Acrocomia aculeata (Jacq.) Lodd. ex. Mart.) were provided by the Basic Processing Unit of Coco Macaúba (UBCM; Riacho D'antas, Montes Claros, Minas Gerais, Brazil; $16^{\circ}$ 25'12"S, 44 18'36"W).

\section{Extraction of Oil Samples}

The oil from the macaúba seeds was extracted by the cold extraction method, where the seeds were pressed with a mechanical press (Scott Tech). The crude oil obtained was centrifuged for $15 \mathrm{~min}$ at 3,500 $\mathrm{rpm}$ to separate the impurities. The buriti oil was supplied (Family Farmers and Agroextractivists Grande Sertão Ltda) and not obtained via extraction. The fruits came from the Januária region $\left(15^{\circ} 26^{\prime} 10^{\prime \prime S}, 44^{\circ}\right.$ $\left.40^{\prime} 44^{\prime \prime} \mathrm{W}\right)$ in the North of Minas Gerais, Brazil.

\section{Chemical Composition of the Oils}

The samples were analysed by gas chromatography coupled with mass spectrometry (GCMS; Perkin Elmer Clarus 560-600 MS, Instrumental Chemistry Laboratory, Institute of Agricultural Sciences at UFMG) that was equipped with a silica capillary column molten DB-5 (30 m length; $0.25 \mathrm{~mm}$ internal diameter; $0.25 \mu \mathrm{m}$ film thickness) and used a helium carrier gas. The injector temperature was $260{ }^{\circ} \mathrm{C}$. The initial column temperature was $100{ }^{\circ} \mathrm{C}$ and was increased to $250{ }^{\circ} \mathrm{C}$ at a rate of $10{ }^{\circ} \mathrm{C} / \mathrm{min}$, remaining at this temperature for $40 \mathrm{~min}$. The detector temperature was $290{ }^{\circ} \mathrm{C}$ at the GC-MS system interface [59]. The mass detector was adjusted to operate with electron impact ionisation $(70 \mathrm{eV})$ and to scan a mass range of 30 to $600 \mathrm{Da}$. The identification of the compounds was carried out by comparing the mass spectra of the samples with those of the known compounds existing in the device database. Literature data and standard samples were also used. For quantitative analysis, the GC-MS apparatus was calibrated with reference compounds that represented the main compound classes present in the samples.

\section{Formation of Chitosan Films (CF), CF Containing buriti Oil (CFB), and CF Containing macaúba Oil (CFM)}

Three formulations of chitosan biopolymer films were produced (Table 1): a standard solution containing $2 \%$ chitosan, another containing $2 \%$ emulsified chitosan and $2 \%$ buriti oil, and the third containing $2 \%$ emulsified chitosan and $2 \%$ macaúba oil. The standard, filmogenic chitosan solution was prepared by dispersing $2 \%$ chitosan (by mass) in $97 \mathrm{~mL}$ of an aqueous acetic acid solution under continuous stirring for $1 \mathrm{~h}$. The stoichiometric amount of acetic acid was calculated from the weight of the sample, considering the degree of acetylation of the chitosan (DA $=18 \%$ ), to obtain the protonation of all $\mathrm{NH}_{2}$ groups. The solution was stirred until the biopolymer chitosan was completely solubilised.

The standard, filmogenic solution was then emulsified at $60{ }^{\circ} \mathrm{C}$ in a mechanical stirrer (Fisaton Mod.713D, São Paulo, Brazil) at 5,000 rpm for $10 \mathrm{~min}$ to give a standard, film-forming solution. The standard solution was distributed in disposable petri dishes and dried in a laminar flow chamber $\left(40{ }^{\circ} \mathrm{C}\right)$ for $24 \mathrm{~h}$. After this period, the chitosan films (CF) were collected. Buriti oil, extracted by the cold pressing method, was added to the standard, filmogenic solution, which was then emulsified by the same process as the CF, to give

Table 1: Composition of Films and Corresponding Nomenclature

\begin{tabular}{|c|c|c|c|}
\hline Nomenclature & CF & CFB & CFM \\
\hline \hline Water $/ \mathrm{mL}$ & 97.00 & 95.00 & 95.00 \\
\hline Chitosan $/ \mathrm{g}$ & 2.00 & 2.00 & 2.00 \\
\hline Acetic acid / $\mathrm{mL}$ & 1.00 & 1.00 & 1.00 \\
\hline Buriti oil /g & - & 2.00 & - \\
\hline Macaúba oil / g & - & - & 2.00 \\
\hline
\end{tabular}


the CF containing buriti oil (CFB). Similarly, macaúba oil, extracted by the cold pressing method, was added to the standard, filmogenic solution and emulsified to give the CF containing macaúba oil (CFM), (Figures $3 a, 3 b$, and $3 c)$ ).

After their preparation, the films were subjected to visual analysis, and their thickness and moisture content were determined, as well as their overall degradability in soil. After each collection, moisture content analysis was also performed on the soil samples.

\section{Water Solubility Analysis}

The analysis was performed according to [60], where the samples were cut $(1 \mathrm{~cm} \times 2 \mathrm{~cm})$ and then stored under UR $=0 \%$ for 7 days. After this period, the samples were submerged in $80 \mathrm{~mL}$ of water at room temperature under continuous agitation (200 rpm) for 1 $\mathrm{h}$, after which the samples were collected and dried $(60$ ${ }^{\circ} \mathrm{C}$ ) until a constant weight was maintained. The measurements were performed in triplicate, and the solubility results were expressed as a percentage according to Equation (1).

Solubility $(\%)=\frac{S w_{\text {inicial }}-S w_{\text {final }}}{\text { peso }_{\text {inicial }}}$

Here, solubility (\%) is the percentage of sample solubility, $S w_{\text {inicial }}$ is the starting weight (initial dry sample weight-before the samples is submerged in water), and $\mathrm{Sw}_{\text {final }}$ is the final sample weight (after the sample constant weight when the sample is exposed to drying under $60^{\circ} \mathrm{C}$ ).

\section{Moisture Content Analysis - Film Samples}

The moisture content was determined for samples CF, CFB, and CFM according to the standards [61-62]. The tests were performed in triplicate and the samples were weighed until they maintained a constant weight. The results are expressed as a percentage according to Equation 2.

$(\%) U_{b s}=\frac{M_{u}-M_{s}}{M_{s}} * 100$

Here, $(\%) U_{\mathrm{bs}}$ is the moisture content concerning the dry base, $M_{\mathrm{u}}$ is the wet mass of the specimen, and $M_{\mathrm{s}}$ is the dry mass of the specimen.

\section{Degradability Analysis}

The biodegradability analysis was performed by gravimetry where the samples of CF, CFB, and CFM films were cut into squares $(1 \mathrm{~cm} \times 1 \mathrm{~cm})$, distributed in nylon bags ( $1 \mathrm{~g}$ per bag), and then buried in soil collected from the UFVJM vegetable garden. The analyses were performed on the samples during collections performed at intervals of 30,60 , and 90 days, where weight loss was calculated according to [63], as illustrated in Equation 3.

$W I(\%)=(W 1-W 2) * 100$

Here, $W I(\%)$ is the weight loss percentage, $W 1$ is the initial weight of the film samples, and $W 2$ is the weight of the film samples after being stored in the soil.

\section{RESULTS AND DISCUSSION}

\section{Chemical Composition of buriti and macaúba Oils}

The dry mass of the buriti mesocarp has an oil content of $42 \%$ [64]. Buriti oil contains saturated fatty acids, such as palmitic and stearic acid, and unsaturated fatty acids, like palmitoleic and linoleic acid (Figure 1 and Table 2). However, oleic acid is the most prevalent fatty acid within the oil $(70 \%)$. Oleic acid is one of the most consumed fatty acids worldwide and provides health benefits. Buriti oil is similar in terms of fatty acid composition to other oilseeds of great commercial value, such as olive, canola, and peanut oils [30], [64]. The oil content in the almonds of macaúba fruits is slightly higher $(55-60 \%)$ than that in the pulp (50-55\%) [65]. Saturated laurate (C 12:0), myristate (C 14:0), and palmitate (C 16:0) esters predominate in this oil (Figure 2, Table 3).

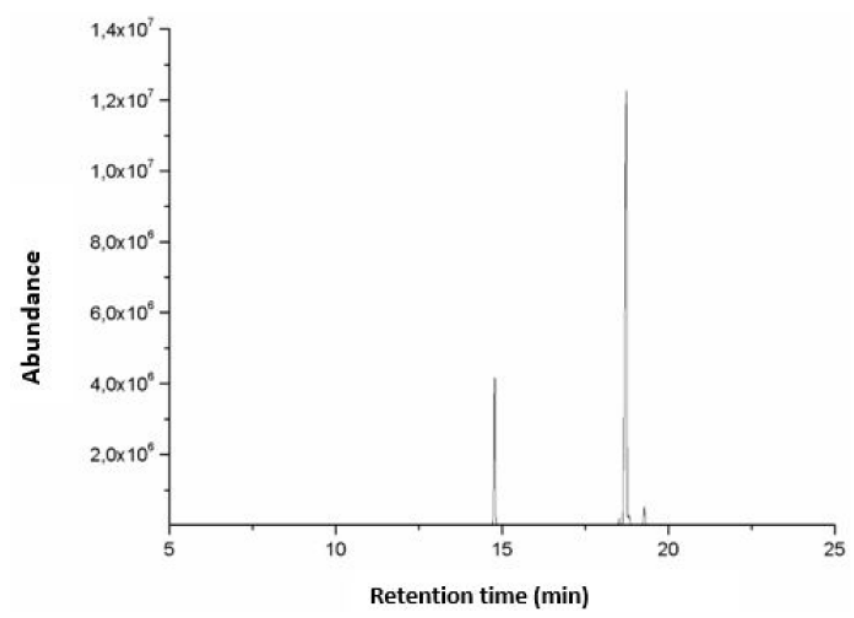

Figure 1: Fatty acid profile Buriti oil.

Oxidative stability is lower when there is a greater number of unsaturated esters present; therefore, the higher percentage of saturated esters in the macaúba oil suggests that this oil and biodiesel from macaúba 
Table 2: Chemical Composition of Buriti Oil

\begin{tabular}{|c|c|c|c|c|}
\hline Peak & $\operatorname{Tr}^{\mathrm{a}}$ & Compounds & Area & Area $(\%)$ \\
\hline 1 & 10.206 & methyl tetradecanoate & 1842274 & 0.08 \\
\hline 2 & 12.421 & methyl pentadecanoate & 1524743 & 0.06 \\
\hline 3 & 14.098 & (Z)-hexadec-9-methyl enoate & 1869194 & 0.08 \\
\hline 4 & 14.201 & (E)-hexadec-9- methyl enoate & 7472080 & 0.31 \\
\hline 5 & 14.741 & methyl hexadecanoate & 646355026 & 26.72 \\
\hline 6 & 16.410 & (Z)-heptadec-9- methyl enoate & 1750063 & 0.07 \\
\hline 7 & 16.963 & methyl heptadecanoate & 2840519 & 0.12 \\
\hline 8 & 18.459 & (9Z,12Z)- methyl-octadeca-9,12-dienoate & 39743073 & 1.64 \\
\hline 9 & 18.673 & (E) and (Z)- octadec-9-methyl enoate & 1603865525 & 69.29 \\
\hline 10 & 19.208 & Methyl Octadecanoate & 91109812 & 3.77 \\
\hline 11 & 22.951 & (Z) -methyl-9-metla enoate & 18463236 & 0.76 \\
\hline 12 & 23.599 & methyl icosanoate & 2559135 & 0.11 \\
\hline
\end{tabular}

${ }^{\mathrm{a}}$ Time retention (min.)

must exhibit good oxidative stability [66]. The filmogenic matrix formation, homogeneity, and colour of the CF, CFB, and CFM samples were analysed, as well as their degradation in soil. The CF was a yellowish colour and transparent, the CFB was a mustard yellow colour, and the CFM were a yellowish/opaque colour (Figures 3a, 3b, and 3c). Furthermore, all three films formed homogeneous filmogenic matrices.

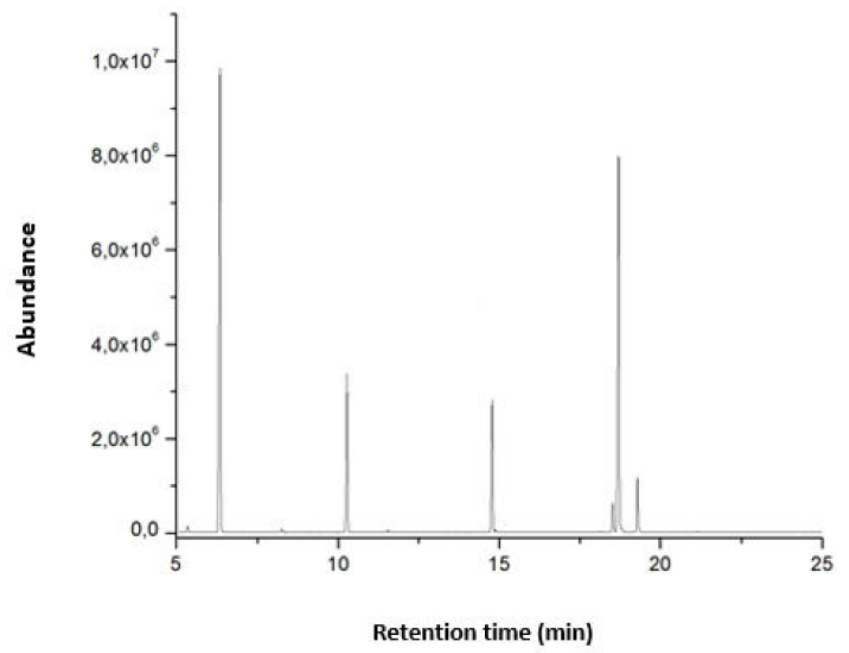

Figure 2: Fatty acid profile Macaúba oil.

\section{Solubility Analysis}

The solubility analysis was performed according to methods of [60], where it was possible to verify differences between the samples. The percentage of water solubility for the CFM samples was approximately twice as high as those of the CF and CFB samples (Table 4).
Other authors have verified that the biodegradation of most films containing $1 \%$ and $2 \%$ of chitosan (by mass) occurred in soil over 5 to 7 days, and the rate of biodegradation increased significantly when the soil moisture was around 50\% [67]. [68]. Reis et al. (2013) [68], also studied soil degradability. In their study, weight loss between film samples containing the only chitosan was compared to samples of emulsified films of chitosan and palmitic acid. During the experiment, it was observed that the film samples containing the only chitosan, presented marked weight loss, which may be related to the solubility of the biopolymer [68]. According to [67], when subjected to gravimetric analysis, chitosan films show considerable weight loss, which occurs as a result of chitosan degradation, not because of its dissolution in a humid environment.

\section{Moisture Content Analysis - CF, CFB, and CFM Samples}

The temperature and relative humidity play an important role in the activity of microorganisms that can bind and degrade biomaterials [8]. Therefore, the rates of chitosan degradation in the different soils, the effects of chitosan on various organisms, and the physicochemical properties of the soils must be investigated [69]. As shown in Table 5, storage conditions such as time, temperature, and moisture content can modify the characteristics and affect the properties of chitosan films [70]. Therefore, because of these effects and the sensitivity of chitosan film degradation to moisture content [71], it is important to evaluate the moisture content of chitosan films. 
Table 3: Chemical Composition of Macaúba Oil

\begin{tabular}{|c|c|c|c|c|}
\hline Peak & $\operatorname{Tr}^{\mathrm{a}}$ & Compounds & Area & Area $(\%)$ \\
\hline 1 & 6.348 & Methyl dodecanoate & 1842274 & 0.08 \\
\hline 3 & 14.761 & Methyl hexadecanoateHexadecanoa & 1869194 & 0.08 \\
\hline 4 & 18.508 & (methyl octadeca-9,12-dienoate & 7472080 & 0.31 \\
\hline 6 & 19.268 & Methyl octadecanoate & 1750063 & 0.07 \\
\hline
\end{tabular}

${ }^{\text {a }}$ Time retention (min.)

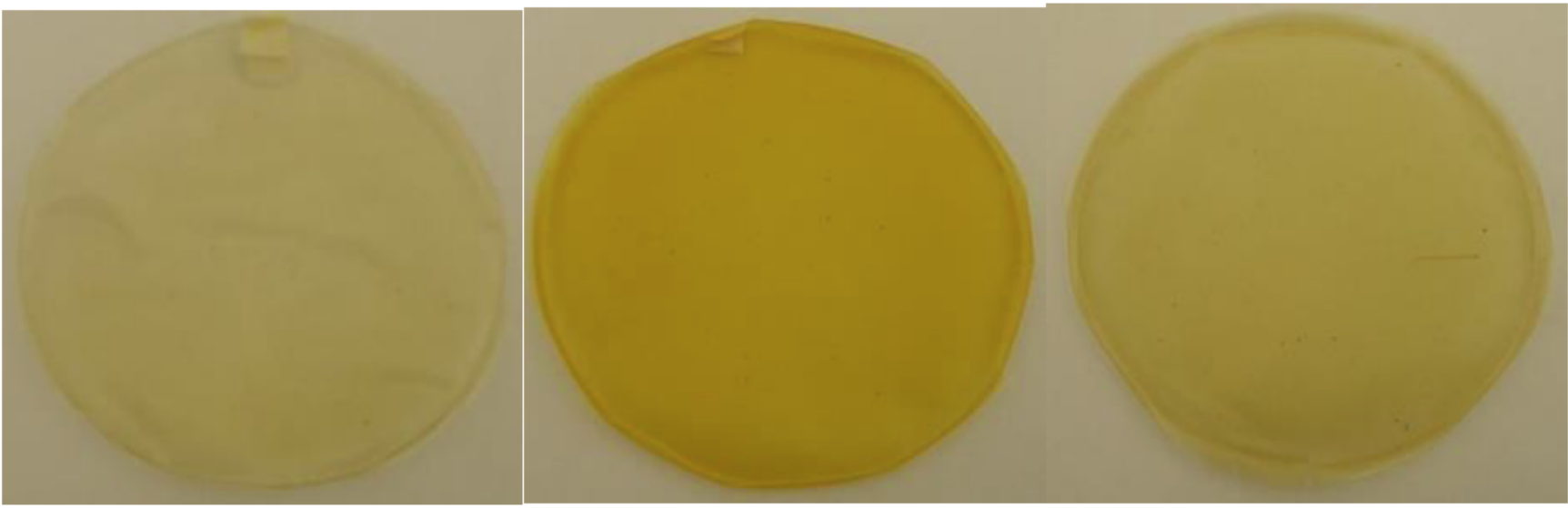

a

Figure 3: Photographs of (a) the chitosan (CF) films, (b) the CF emulsified with buriti oil (CFB), and (c) the CF emulsified with macaúba oil (CFM).

Table 4: Average Solubility (\%) of Samples CF, CFB e CFM

\begin{tabular}{|c|c|}
\hline Samples & Solubility (\%) \\
\hline \hline CF & $2.22^{\mathrm{a}}$ \\
\hline CFB & $2.11^{\mathrm{a}}$ \\
\hline CFM & $4.37^{\mathrm{b}}$ \\
\hline
\end{tabular}

${ }^{a-b}$ The means in the same column with significantly different envelopes ( $p \leq 0.05$ ) according to the Tukey test.

Table 5: Moisture Content (\%) of Samples CF, CFB e CFM

\begin{tabular}{|c|c|c|c|}
\hline \multirow{2}{*}{ Samples } & \multicolumn{3}{|c|}{ Storage time (time) } \\
\cline { 2 - 4 } & $\mathbf{3 0}$ & $\mathbf{6 0}$ & $\mathbf{9 0}$ \\
\hline \hline CF & $19.20^{\mathrm{a}}$ & $40.34^{\mathrm{a}}$ & $54.78^{\mathrm{a}}$ \\
\hline CFB & $7.26^{\mathrm{b}}$ & $29.03^{\mathrm{b}}$ & $35.32^{\mathrm{b}}$ \\
\hline CFM & $7.63^{\mathrm{b}}$ & $44.83^{\mathrm{a}}$ & $93.86^{\mathrm{c}}$ \\
\hline
\end{tabular}

${ }^{a-c}$ The means in the same column with significantly different envelopes $(p \leq 0.05)$ according to the Tukey test.

Amaral et al. (2017) [72] reported a study on the diffusion process of chitosan films with the addition of oils from the Arecaceae family, where they concluded that the diffusion coefficient was statistically different between the CF, CFB, and CFM samples. They predicted this may be associated with the formation of matrices with small micropores that facilitate the passage of moisture. Furthermore, [68] developed 
chitosan films with the addition of fatty acids that exhibited reduced water vapour permeability [73] carried out studies using a foliar application of different chitosan doses in corn plants subjected to water deficit, where they observed behavioural responses similar to those of plants under favourable conditions of irrigation. According to [74], chitosan induces mechanisms against various biotic stresses, such as those caused by fungi, bacteria, and insects, and promotes the formation of protective barriers that increase plant productivity and stimulate physiological responses to water deficit tolerance.

Pastucha (2008) [75] evaluated chitosan application in different stages of soybean plant development and observed that when chitosan was applied to seeds, seedlings, and early flowers, there was greater efficiency in inhibiting infections compared to when the chitosan was only applied in the period of soy development. According to [64], this result may be because the treatment of seeds with chitosan activates biochemical mechanisms of resistance, which was expressed by the increase in enzymatic activity involving chitinases and $\beta$-1,3-glucanases.

The CFB samples showed the lowest moisture content out of the three samples (Table 5). Based on this, we assumed that there were interactions between the buriti oil and the chitosan biopolymer. This combination of the oil and chitosan likely formed a moisture barrier that allowed for the low moisture content. This evidence shows that these films deserve further investigation for their possible application in the packaging sector.

\section{Biodegradability Analysis}

Organisms that are naturally found in the soil, commonly called the microbial community, consist of various, heterogeneous populations that are difficult to uniformly sample. Therefore, some parameters of the biodegradability studies should be re-evaluated in greater detail. If chitosan biopolymers are to be used in packaging, their biodegradability upon disposal in soil and landfills should be evaluated. This was achieved through biodegradation tests, which simulate the disposal of these materials in the soil. One test simulates the degradation of these materials in common soil, where it was possible to measure or predict many microorganisms capable of using these materials as a substrate. This would result in the consumption of the material by the microorganisms, which would be a positive response as it implies the possibility of this alleged packaging material being biodegradable.

We observed that the CFB samples showed greater weight reduction during the collections performed after 30,60 , and 90 days (Table $\mathbf{6}$ ). This can be attributed to the plasticising characteristic of buriti oil, as it presents a percentage of degradation $(\mathrm{X} \%)$ higher than those of CF and CFM samples, $90 \%$ and $60 \%$, respectively. A similar result was obtained by [68] using chitosan film samples with palmitic acid (16:0) and stearic acid (18:0).

Buriti pulp oil has high percentages of oleic (18:1), linoleic (18:2), and linolenic (18:3) unsaturated fatty acids and low percentages of saturated fatty acids [76]. Unsaturated fatty acids are more unstable and therefore more susceptible to oxidation, which supposedly explains the greater degradability of CFB samples, compared to that of CF and CFM samples. Hence, it can be inferred that the high degradation of the CFB samples may also be related to the availability of nutrients present upon their disposition in the soil, as well as their potential to serve as a substrate for the soil microbial community and other organic matter.

Wild et al. (2019) [77] concluded that the decomposition of organic matter present in the soil is interactively controlled by several mechanisms, including the balance between the availability of carbon versus nitrogen. However, more in-depth studies are needed to understand the carbon and nitrogen cycle on an ecosystem scale [77], especially when considering the use of CFB in packaging.

Table 6: Percentage of Degradation in Soil-Samples CF, CFB and CFM

\begin{tabular}{|c|c|c|c|}
\hline \multirow{2}{*}{ Samples } & \multicolumn{2}{|c|}{ Storage times (days) } \\
\cline { 2 - 4 } & $\mathbf{3 0}$ & $\mathbf{6 0}$ & $\mathbf{9 0}$ \\
\hline \hline CF & $1.23^{\mathrm{a}}$ & $10.40^{\mathrm{a}}$ & $14.50^{\mathrm{a}}$ \\
\hline CFB & $1.67^{\mathrm{b}}$ & $8.53^{\mathrm{b}}$ & $16.00^{\mathrm{b}}$ \\
\hline CFM & $0.83^{\mathrm{c}}$ & $9.27^{\mathrm{c}}$ & $9.57^{\mathrm{c}}$ \\
\hline
\end{tabular}

${ }^{a-b}$ The means in the same column with significantly different envelopes $(p \leq 0.05)$ according to the Tukey test. 
The availability of carbon and nitrogen in the soil depends on the decomposition of soil polymers, such as lignin, chitin, and proteins, which represent the largest fraction of carbon and nitrogen in the soil and are too large for immediate absorption by plants and microorganisms. Microorganisms can adjust the production of enzymes targeting different polymers to optimise the balance between the availability of and demand carbon and nitrogen [77]. This commonly occurs in the rhizosphere, the region of the soil where the highest concentrations of carbon and nitrogen are found in the microbial community, given the availability of nutrients and the quality of substrates. Considering the chitosan biopolymer composition, it is suggested that this effect is similar. As chitin is difficult to degrade because of its physicochemical properties, some organisms contain a large repertoire of chitinolytic enzymes for more effective degradation. These include actinomycetes, streptomycetes, and soil saprophytic bacteria among others [78-80], in their work on degradability, observed an increase in the development of actinobacteria in soil that were subjected to a chitosan biopolymer energy source.

Mostafa et al. (2010) [8] observed no weight loss of plastic films during their degradation in sandy soil, but the weight of the chitosan film was reduced significantly (up to $16 \%$ ) after two months and reached $100 \%$ after four months [81] measured the rate of chitosan degradation by burying nylon nets imbued with chitosan flakes ( $1 \%$ by weight) and measured the weight of the remaining chitosan flakes in the nets after 180 days. The weight of the chitosan flakes had decreased by $60 \%$ by the end of the experimental period.

According to [17], the presence and rate of microorganism activity in the soil can affect the chitosan degradation capacity when subjected to degradation studies in different soils. [38] compared the use of glycerol and buriti oil as plasticisers in blends of polystyrene (PS) and thermoplastic starch (TPS). They concluded that PS/TPS blends with glycerol degraded after a greater number of stages and at higher temperatures than those produced with buriti oil, suggesting that buriti oil produces more thermally stable blends when used as a plasticiser for starch. Therefore, the materials produced with buriti oil present a better plasticizing effect and a greater susceptibility to soil degradation than blends produced with glycerol. Furthermore, it is important to emphasise that macaúba seed oil has a higher percentage of saturated fatty acids than that of buriti oil (Figures 4 and 5).

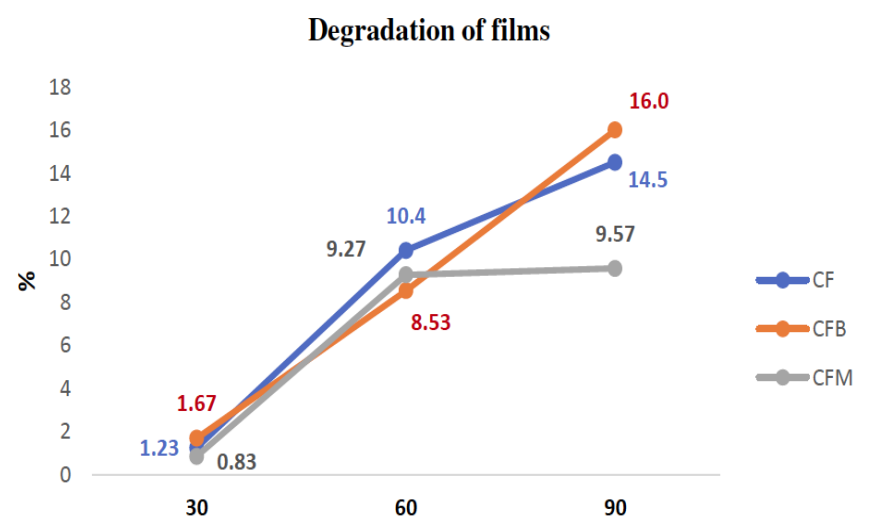

Figure 4: Graph of sample degradation (CF); (CFB) e (CFM).

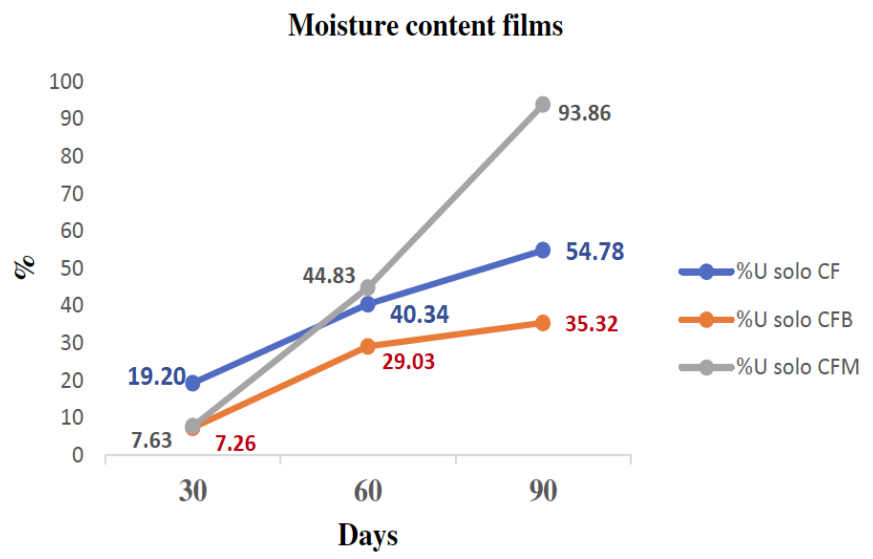

Figure 5: Graph of the moisture content of the samples (CF); (CFB) e (CFM).

\section{CONCLUSION}

The fabricated CF, CFB, and CFM samples showed statistically significant differences in their solubility, moisture content, and degradability in soil, which were all analysed by gravimetry. These differences were more pronounced for CFB samples, which, because they had a lower moisture content in all collection times, also showed twice less solubility when compared to CFM samples and, in parallel, in soil degradability analysis, CFB samples showed greater weight reduction during the collections performed in the periods of 30, 60 and 90 days. The CFB samples showed a percentage of degradation $(\mathrm{X} \%)$ higher than that of the CF and CFM samples, in the order of $90 \%$ and $60 \%$, respectively. This fact shows the greater interaction of buriti oil as a plasticizer. However, to provide more concise and targeted evidence, further studies are needed on the applicability of using chitosan films and oils from species of the Aracaceae family (Mauritia flexuosa L.f. and Acrocomia aculeata) in the packaging sector. 


\section{ACKNOWLEDGMENTS}

The authors would like to thank the GEPAEQ-Group of Studies and Research Applied to Chemical Engineering at UFVJM-Federal University of Vales do Jequitinhonha and Mucuri-Diamantina-MG / Brazil.

\section{APPENDIX}

\begin{tabular}{|c|c|}
\hline Symbol & $=$ Definition \\
\hline Solubility (\%) & $=$ Percentage of sample solubility \\
\hline$S W_{\text {inicial }}$ & $=$ Initial sample weight \\
\hline$S w_{\text {final }}$ & $=$ Final sample weight \\
\hline$(\%) U_{\mathrm{bs}}$ & $\begin{array}{l}=\text { Moisture content in relation to the dry } \\
\text { base }\end{array}$ \\
\hline$M_{\mathrm{u}}$ & $=$ Wet mass of the specimen \\
\hline$M_{\mathrm{s}}$ & $=$ Dry mass of the specimen \\
\hline$W I(\%)$ & $=$ Weight loss percentage \\
\hline$W 1$ & $=$ Initial weight of the film samples \\
\hline$w 2$ & $\begin{array}{l}=\text { Weight of the film samples after being } \\
\text { stored in the soil }\end{array}$ \\
\hline
\end{tabular}

\section{REFERENCES}

[1] Chamas A, Moon H, Zheng J, Qiu Y, Tabassum T, Jang JH, Suh, S. Degradation Rates of Plastics in the Environment. ACS Sustainable Chemistry \& Engineering 2020 https://doi.org/10.1021/acssuschemeng.9b06635

[2] Barnabas SG, Sivakumar GD, Satish PG, Vasantha Geethan KA, Kumar SP, Prithvi Rajeevan P, Kumar PD. Solid waste management across the World-a review. Eco Env \& Cons 2017; 23(February Suppl.).

https://doi.org/10.13140/RG.2.2.31991.57768

[3] Gonçalves ATT, Moraes FTF, Marques GL, Lima JP, Lima RS. Urban solid waste challenges in the BRICS countries: a systematic literature review. Rev Ambient Água 2018; 13(2): Epub Apr 16.

https://doi.org/10.4136/ambi-agua.2157

[4] Kaza S, Yao L, Bhada-Tata P and Van Woerden, F. What a Waste 2.0: A Global Snapshot of Solid Waste Management to 2050 (c) 2018 International Bank for Reconstruction and Development / The World Bank 1818 H Street NW, Washington, DC 20433 Telephone: 202-473-1000; Internet: www.worldbank.org.Published: December 2018. ISBN: 9781-4648-1329-0. e-ISBN: 978-1-4648-1347-4 https://doi.org/10.1596/978-1-4648-1329-0

[5] Geyer R, Jambeck JR, Law KL. Production, use, and fate of all plastics ever made. Sci. Adv., New York, 2017; 3: 6. https://doi.org/10.1126/sciadv.1700782

[6] Baconguis B. "Stemming the Plastic Flood." A Break Free from Plastic Movement Report, 2018. https://www.breakfreefromplastic.org/wpcontent/uploads/2018/04/Stemming-the-plastic-floodreport.pdf.
Siracusa V, Rocculi P, Romani S, Rosa MD. Biodegradable polymers for food packaging: a review. Trends in Food Science \& Technology 2008; 19(12): 634-643. https://doi.org/10.1016/j.tifs.2008.07.003

[8] Mostafa HM, Sourell H, Bockisch FJ. The Mechanical Properties of Some Bioplastics Under Different Soil Types for Use as a Biodegradable Drip Tubes. Agricultural Engineering International: the CIGR Ejournal. Manuscript 1497. Vol. XII. March, 2010. https://www.researchgate.net/publication/ 277994731 Mechanical properties of some bioplastics un der_different_soil_types_used_as_biodegradāble_drip_tūbes

[9] Ilgenfritz EM. Plastics waste handingpractices in solid waste management. Water Air Soil Pollut 1975; 4: 191-199. https://doi.org/10.1007/bf00160445

[10] Andreeßen C, Steinbüchel A. Desenvolvimentos recentes em biopolímeros não biodegradáveis: precursores, processos de produção e perspectivas futuras. Microbiologia e Biotecnologia Aplicadas 2018.

https://doi.org/10.1007/s00253-018-9483-6

Franchetti SMM, Marconato JC. Biodegradable polymers - a partial way for decreasing the amount of plastic waste. Polímeros biodegradáveis - uma solução parcial para diminuir a quantidade dos resíduos plásticos. Química Nova 2006; 29(4): São Paulo jul./ago. https://doi.org/10.1590/S0100-40422006000400031

[12] Queiroz AUB, Queiroz PC. Innovation and Industrial Trends in Bioplastics, Polymer Reviews 2009; 49(2): 65-78. https://doi.org/10.1080/15583720902834759

[13] David E, Chie Hoon S, Alexander S, Jens L. Technology Trends in Biodegradable Polymers: Evidence from Patent Analysis. Polymer Reviews 2016; 56(4): 584-606. https://doi.org/10.1080/15583724.2015.1125918

[14] Wróblewska-Krepsztul J, Rydzkowski T, Borowski G, Szczypiński M, Klepka T \& V K Thakur. Recent progress in biodegradable polymers and nanocomposite-based packaging materials for sustainable environment. International Journal of Polymer Analysis and Characterization 2018; 23: 383-395 https://doi.org/10.1080/1023666X.2018.1455382

[15] Siracusa V. Microbial Degradation of Synthetic Biopolymers Waste Polymers 2019; 11: 1066 https://doi.org/10.3390/polym11061066

[16] Fernandes SS, Romani VP, da Silva FG, Martins, GV. Chia seeds to develop new biodegradable polymers for food packaging: Properties and biodegradability Polymer Engineering and Science 2020 https://doi.org/10.1002/pen.25464

[17] Wieczorek AS, Hetz SA, Kolb S. Microbial responses to chitin and chitosan in oxic and anoxic agricultural soil slurries. Biogeosciences 2014; 11: 3339-3352. https://doi.org/10.5194/bg-11-3339-2014

[18] Mohamad R, Aishah S, Osman Z. Antimicrobial properties and degradadtion weight loss and morphology of LLDPE/Chitosan blend. International Journal of Advances in Science Engineering and Technology, ISSN: 2321-9009. http://www.iraj.in/journal/journal file/journal pdf/6-2051449222604167-172.pdf

[19] Mohandas A, Deepthi S, Biswas R, Jayakumar R. Chitosan based metallic nanocomposite scaffolds as antimicrobial wound dressings. Bioactive Materials 2017. https://doi.org/10.1016/j.bioactmat.2017.11.003

[20] Rollini M, Mascheroni E, Capretti G, Coma V, Musatti A Piergiovanni L. Propolis and chitosan as antimicrobial and polyphenols retainer for the development of paper based active packaging materials. Food Packaging Shelf Life 2017 14: $75-82$ https://doi.org/10.1016/j.fpsl.2017.08.011

[21] Chen CH, Wang FY, Mao CF, Liao WT, Hsieh CD. Studies of chitosan. II. Preparation and characterization of 
chitosan/poly(vinylalcohol)/gelatin ternary blend films. International Journal of Biological Macromolecules 2008; 43: 37-42.

https://doi.org/10.1016/j.ijbiomac.2007.09.005

[22] Muxika A, Etxabide A, Uranga J, Guerrero P, de la Caba K. Chitosan as a bioactive polymer: processing, properties and applications. Int J Biol Macromol 2017; 105: 1358-1368. https://doi.org/10.1016 / j.ijbiomac.2017.07.087

[23] Beier S, Bertilsson S. Bacterial chitin degradationmechanisms and ecophysiological strategies. Frontiers in Microbiology 2013; 4: 149.

https://doi.org/10.3389/fmicb.2013.00149

[24] Aam BB, Heggset EB, Norberg AL, Sørlie M, Vårum KM, Eijsink VGH. Production of Chitooligosaccharides and Their Potential Applications in Medicine. Marine Drugs 2010; 8(5): 1482-1517.

https://doi.org/10.3390/md8051482

[25] Zhang M, Li XH, Gong YD, Zhao NM, Zhang XF. Properties and biocompatibility of chitosan films modified by blending with PEG. Biomaterials 2002; 23(13): 2641-2648. https://doi.org/10.1016/s0142-9612(01)00403-3

[26] Barra A, Alves $Z$, Ferreira NM, Martins MA, Oliveira $H$, Ferreira LP, Cruz MM, Carvalho MD, Neumayer SM, Rodrigues BJ, Nunes C, Ferreira P. Biocompatible chitosanbased composites with properties suitable for hyperthermia therapy. Journal of Materials Chemistry B., 2020. https://doi.org/10.1039/C9TB02067E

[27] Piotrowska-Kirschling A, Brzeska J. The Effect of Chitosan on the Chemical Structure, Morphology, and Selected Properties of Polyurethane/Chitosan Composites. Polymers 2020; 12: 1205. https://doi.org/10.3390/polym12051205

[28] Cândido TLN, Silva MR, Agostini-Costa TS. Bioactive compounds and antioxidant capacity of buriti (Mauritia flexuosa Lf) from the Cerrado and Amazon biomes. Food Chemistry 2015; 177: 313-319. https://doi.org/10.1016/.j.foodchem.2015.01.041

[29] Pelosi MS, Leite I, Passos L, Ferreira C, Sabaa-Srur AUO, Fialho E. Phisico-chemical evaluation and antioxidant capacity of buriti extract and antitumor activity in breast câncer cell line. Brazilian Journal of Development 2020; MDA-MB-231. 2020.

https://doi.org/10.34117/bjdv6n4-064

[30] Pereira Freire JA, Barros KBNT, Lima LKF, Martins JM, Araújo YdC, da Silva Oliveira GL, de Souza Aquino J, Ferreira PMP. Phytochemistry Profile, Nutritional Properties and Pharmacological Activities of Mauritia flexuosa. Journal of Food Science 2016; 81: R2611-R2622. https://doi.org/10.1111/1750-3841.13529

[31] RIOS, Mary Naves da Silva; PASTORE JÚNIOR, Floriano (org.). Plantas da Amazônia: 450 espécies de uso geral. Brasília: Universidade de Brasília, Biblioteca Central 2011; 3378 p., il. Disponível em: http://repositorio.unb.br/ handle/10482/35458

[32] Carneiro TB, Carneiro JGM. Frutos e polpa desidratada buriti (Mauritia flex uosa I.): aspectos físicos, químicos e tecnológicos. Revista Verde, Mossoró 2011; 6: 105-111. https://pdfs.semanticscholar.org/3fd6/3817d274c5a2ea0ca80 7cab9d8331a370dee.pdf

[33] Sandri DO, Xisto ALRP, Rodrigues EC, Morais EC, Barros WM. Antioxidant, activity and physicochemical characteristics of buriti pulp (Mauritia flexuosa) collectted in the of Diamantino-MTS. Rev Bras Frutic 2017; 39(3): Jaboticabal July/Aug. 2017 Epub Aug 07. https://doi.org/10.1590/0100-29452017864

[34] Carvalho JO, Orlanda JFF. Heat stability and effect of $\mathrm{pH}$ on enzyme activity of polyphenol oxidase in buriti (Mauritia flexuosa Linnaeus f.) fruit extract. Food Chemistry 2017; 233: 159-163.

https://doi.org/10.1016/j.foodchem.2017.04.101
[35]

Becker MM. Characterization of native fruits of the Amazon region and development of na amperometric biosensor for determination of antioxidante capacity. Tese de doutorado. Universite de Perpignan via Domitia et Universidade Federaldo Maranhão. Brazil-France. September/2019. https://tel.archives-ouvertes.fr/tel-02458919/document

[36] Nonato CFA, Leite DOD, Pereira RC, Boligon AA, RibeiroFilho J, Rodrigues FFG, da Costa JGM. Chemical analysis and evaluation of antioxidant and antimicrobial activities of fruit fractions of Mauritia flexuosa L. f. (Arecaceae). Peer J 2018; 6: e5991. https://doi.org/10.7717/peerj.5991

[37] Koolen HH, da Silva FM, Gozzo FC, de Souza AQ, de Souza $A D$. Antioxidant, antimicrobial activities and characterization of phenolic compounds from buriti (Mauritia flexuosa L. f.) by UPLC-ESI-MS/MS. Food Research International 2013; 51(2): 467-473.

https://doi.org/10.1016/j.foodres.2013.01.039

[38] Preparation, Characterization and Degradation of PS/TPS Blends Using Glycerol and Buriti oil as Plastiscizers. Daniela Schlemmerl; Maria J. A. Salesl; Inês S. Resckll Polímeros: Ciência e Tecnologia 2010; 20(1): 6-13,. https://doi.org/10.1590/S0104-14282010005000002

[39] Oliveira DA, Melo Júnior AF, Brandão MM, Rodrgues LA Menezes EV, Ferreira, PRB. Genetic diversity in populations of Acrocomia aculeata (Arecaceae) in the northern region of Minas Gerais, Brazil. Genet Mol Res 2012; 11(1): 531-538. https://doi.org/10.4238/2012.March.8.1

[40] Leitman P, Soares K, Henderson A, Noblick L, Martins RC 2015. Arecace hamae in Lista de Espécies da Flora do Brasil. 2015; Jardim Botânico do Rio de Janeiro. Disponível em: $\quad<$ http://floradobrasil.jbrj.gov.br/jabot/floradobrasil/ FB15663>

[41] Lorenzi GMAC. Acrocomia aculeata (Jacq.) Lodd. ex Mart. Arecaceae: bases para o extrativismo sustentável. 2006, Tese Doutorado em Ciências Agrárias, 156f.. Programa de Pós-Graduaçăo em Agronomia. Universidade Federal do Paraná. https://acervodigital.ufpr.br/handle/1884/5279

[42] Costa SEL, Santos RCS, Castro RVO, Castro AFNM, Magalhães, MA, Carneiro ACO, Santos C PS, Gomes IRF e Rocha SMG. Rev. Árvore 2019; 43(5): Viçosa, Epub Nov 25. Briquetes quality produced with the macaúba epicarp (Acrocomia aculeata) and Pinus sp. Wood. https://doi.org/10.1590/1806-90882019000500001

[43] Coelho NHP, Tambarussi EV, Aguiar BI, Roque RH, Portela RM, Braga RC, Gandara FB. Understanding genetic diversity, spatial genetic structure, and mating system through microsatellite markers for the conservation and sustainable use of Acrocomia aculeata (Jacq.) Lodd. Ex Mart. Conservation Genetics 2018; 19(4): 879-891. https://doi.org/10.1007/s10592-018-1061-z

[44] Portela, RM. Tamanho efetivo e fluxo gênico em populações de Acrocomia aculeata (Jacq.) Lodd. ex Mart. Usando a teoria da coalescência. Dissertação de mestrado 2019. IratiPR.

https://doi.org/10.13140/RG.2.2.29853.87527

[45] Prado RG, Almeida GD, de Oliveira AR, de Souza PMTG Cardoso CC, Constantino VR-L, Pasa VMD. Ethanolysis and Methanolysis of Soybean and Macauba Oils Catalyzed by Mixed Oxide Ca-Al from Hydrocalumite for Biodiesel Production. Energy \& Fuels 2016; 30(8): 6662-6670. https://doi.org/10.1021/acs.energyfuels.6b00005

[46] Damasceno SM, Ferraz V, Nelson DL, Fabris JD. Selective adsorption of fatty acid methyl esters onto a commercial molecular sieve or activated charcoal prepared from the Acrocomia aculeata cake remaining from press-extracting the fruit kernel oil . AIMS Energy 2018; 6(5): 801-809. https://doi.org/10.3934/energy.2018.5.801 
[47] Colombo CA, Chorfi Berton LH, Diaz BG, Ferrari RA. Macauba: a promising tropical palm for the production of vegetable oil 2017; OCL, 25: 1 https://doi.org/10.1051/ocl/2017038

[48] Silva GN, Grossi JAS, Carvalho MS, Kuki, KN, Goulart SM, Pimentel LD. Air drying of macauba fruits: maintaining oil quality for biodiesel production. Acta Scientiarum Agronomy 2020; 42: e43451.

https://doi.org/10.4025/actasciagron.v42i1.43451

[49] Da Silva JQ, Santos DQ, Fabris JD, Leonardi Harter LV, Chagas SP. Light biodiesel from macaúba and palm kernel: Properties of their blends with fóssil kerosene in the perspective of na alternative aviation fuel renewable. Renewable Energy 2019. https://doi.org/10.1016/i.renene.2019.11.035

[50] Tilahun WW, Grossi SJA, Favaro SP. Mesocarp oil quality of macauba palm fruit improved by gamma irradiation in storage. Radiation Physics and Chemistry 2020; 168: 108575.

https://doi.org/10.1016/j.radphyschem.2019.108575

[51] Lieb VM, Schex R, Esquivel P, Jiménez VM, Schmarr H-G, Carle R, Steingass, CB. Fatty acids and triacylglycerols in the mesocarp and kernel oils of maturing Costa Rican Acrocomia aculeata fruits. NFS Journal 2019 https://doi.org/10.1016/j.nfs.2019.02.002

[52] Oliveira DM, Clemente E, Costa JMC. Bioactive compounds and physicochemical parameters of grugru palm (Acrocomia aculeata) from Brazil: pulp and powder. Food Sci Technol Res 2014; 20(1): 7-12. https://doi.org/10.3136/fstr.20.7

[53] Nunes AA, Favaro SP, Galvani F, Miranda CHB. Good practices of harvest and processing provide high quality Macauba pulp oil. European Journal of Lipid Science and Technology 2015; 117(12): 2036-2043. https://doi.org/10.1002/ejlt.201400577

[54] Del Río JC, Evaristo AB, Marques G, Martín-Ramos P, Martín-Gil J, Gutiérrez A. Chemical composition and thermal behavior of the pulp and kernel oils from macauba palm (Acrocomia aculeata) fruit. Industrial Crops and Products 2016; 84: 294-304.

https://doi.org/10.1016/j.indcrop.2016.02.018

[55] Favaro SP, Tapeti CF, Miranda CHB, Ciaconini GC, Miyahira MAM, Roscoe R. Macauba (Acrocomia aculeata) pulp oil quality is negatively affected by drying fruits at $60^{\circ} \mathrm{C}$. Braz. arch. biol. technol. Curitiba. 2017; 60: Epub May 02 https://doi.org/10.1590/1678-4324-2017160373

[56] Roberston GL. Food Packaging Principles and Practice, third ed., CRC Press, Taylor and Francis Group, Boca Raton, 696p. 13: 978-1-4398-6242-1 (eBook - PDF). 2012. https://www.academia.edu/19121118/Food_Packaging_Princ iples_and_Practice_3rd_Edition_Robertson_2012_

[57] Priyadarshi R, Rhim JW. Chitosan-based biodegradable functional films for food packaging applications. Innovative Food Science \& Emerging Technologies 2020; 102346. https://doi.org/10.1016/j.ifset.2020.102346

[58] Souza VGL, Pires JRA, Rodrigues C, Coelhoso IM, Fernando ALA. Chitosan Composites in Packaging Industry-Current Trends and Future Challenges. Polymers 2020; 12(2): 417. https://doi.org/10.3390/polym12020417

[59] Collins CH, Braga GL, Bonato PS. Fundamentos de cromatografia. Campinas: Editora da UNICAMP, 2006; P. 452

[60] Zamudio-Flores PB, Torres AV, Salgado-Delgado R, BelloPérez LA. Influence of the oxidation and acetylation of banana starch on the mechanical and water barrier properties of modifies starch/chitosan blend films. Journal of Applied Polymer Science 2010; 115: 991-998.

https://doi.org/10.1002/app.31047
[61] American Standard for Testing and Methods D644-99(2007Standard Test Method for Moisture Content of Paper and Paperboard by Oven Drying (Withdrawn 2010) - Annual book of American Standard Testing Methods. ASTM, Philadelphia, 2000.

[62] NBRNM-ISO287 de 05/2012 - Papel e cartão - Determinação do teor de umidade de um lote - Método por secagem em estufa (ISO 287:2009, IDT)

[63] Khan MA, Bhattacharia SK, Kader MA, Bahari, K Preparation and characterization of ultra violet (UV) radiation cured bio-degradable films of sago starch/PVA blend Carbohydrate Polymers 2006; 63: 500-506. https://doi.org/10.1016/j.carbpol.2005.10.019

[64] Rocha SM, Arrudas SR, Costa FM. Fidêncio PH, Rodrigues MTOS, Silva DS, Nunes YRF, Cardoso Filho O. Efeito do armazenamento nas propriedades físico-químicas do óleo de Macaúba flexuosa L.f. (Aracaceae). Caderno de Ciências Agrárias 2017; 9: 31-37.

\section{https://doi.org/10.35699/2447-6218.2017.2947}

[65] Coimbra MC, Jorge N. Fatty acids and bioactive compounds of the pulps and kernels of Brazilian palm species, guariroba (Syagrus oleraces), jeriva (Syagrus romanzoffiana) and macauba (Acrocomia aculeata). Journal of the Science of Food and Agriculture 2012; 92(3): 679-684. https://doi.org/10.1002/jsfa.4630

[66] Arrudas SR, Fidêncio PH, Silvério FO, Franco MM, Silva DS Pimenta MAS. Study of storange conditio non the physicochemical properties of biodiesel derived from macaúba palm (Acrocomia aculeata) oil using multivariate analysis. Aust J Crop Sci 2018; 12: 1702-1709. https://www.researchgate.net/deref/http\%3A\%2F\%2Fdx.doi.o rg\%2F10.21475\%2Fajcs.18.12.11.p1100

[67] Vikhoreva GA, Kil'Deeva NR, Ustinov MY, Nochevkina YN. Fabrication and study of the degradation of chitosan films. Fibre Chemistry 2002; 34(6). https://doi.org/10.1023/A:1022904023526

[68] Reis AB, Yoshida CMP, Vilela ESD, Nascimento RS, Melo IS, Franco TT. Biodegradability Kraft Paper Coated with Films Emulsified Chitosan and Palmitic Acid. Journal of Research Updates in Polymer Science 2013; 2: 122-131. https://doi.org/10.6000/1929-5995.2013.02.02.6

[69] Sawaguchi A, Ono S, Ooomura M, Inami K, Kumeta $Y$, Honda K, Sameshima-Saito R, Sakamoto K, Ando A, Saito A. Chitosan degradation and associated changes in bacterial community structures in two contrasting soils, Soil Science and Plant Nutrition 2015. https://doi.org/10.1080/00380768.2014.1003965

[70] Zhong Y, Li YF. Effects of storage conditions and acid solvent types on structural, mechanical and physical properties of kudzu starch (Pueraria lobata)-chitosan composite films. Starch 2011; 63(9): 579-586. https://doi.org/10.1002/star.201500033

[71] Nakashima T, Nakano Y, Bin Y, Matsuo M. Biodegradation characteristics of chitin and chitosan films. Journal of Home Economics of Japan 2005; 56(12): 889-897. https://doi.org/10.11428/jhej1987.56.889

[72] Amaral IBC, Arrudas SR, Meira JR, Reis AB. Análise do processo difusivo de filmes de quitosana contendo óleo de palmeiras (Aracaceae) do cerrado brasileiro. Revista Unimontes Científica 2017; 19(2). http://www.ruc.unimontes. br/index.php/unicientifica/article/view/642

[73] Almeida LG, Magalhães PC, Karam D, Silva EM, Alvarenza AA. Chitosan application in the induction of water deficit tolerance in maize plants. Acta Scientiarum. Agronomy 2020; 42. https://doi.org/10.4025/actasciagron.v42i1.42463

[74] Katiyar D, Hemantaranjan A, Singh B. Chitosan as a promising natural compound to enhance potential physiological responses in plant: a review. Ind J Plant Physiol 2015; 20(1): $1-9$. 
[75] Pastucha A. Chitosan as a compound inhibiting the occurence of soybean diseases. Acta Scientiarum Polonorum, Hortorum Cultus 2008; 7(3): 41-55. http://www.acta.media.pl/pl/action/getfull.php?id=1975

[76] Cândido TLN, Silva MR. Comparison of the physicochemical profiles of buriti from the Brazilian Cerrado and the Amazon region. Food Science and Technology 2017; 37: 78. https://doi.org/10.1590/1678-457x.32516

[77] Wild B, Li J, Pihlblad J, Bengtson P, Rütting T. Decoupling of priming and microbial $\mathrm{N}$ mining during a short-term soil incubation. Soil Biology and Biochemistry 2018. https://doi.org/10.1016/j.soilbio.2018.11.014

[78] Saito Y, Yamanushi T, Oka T, Nakano A. Identification of SEC12, SED4, truncated SEC16, and EKS1/HRD3 as multicopy suppressors of ts mutants of sari GTPase. The Journal of Biochemistry 1999; 125(1): 130-137. https://doi.org/10.1093/oxfordjournals.jbchem.a022249
[79] Heggset EB, Tuveng TR, Hoell IA, Liu Z, Eijsink VGH, Vårum KM. Mode of Action of a Family 75 Chitosanase from Streptomyces avermitilis. Biomacromolecules 2012; 13(6): 1733-1741.

https://doi.org/10.1021/bm201521h

[80] Sato K, Azama Y, Nogawa M, Taguchi G, Shimosaka M. Analysis of a change in bacterial community in different environments with addition of chitin or chitosan. Journal of Bioscience and Bioengineering 2010; 109(5): 472-478. https://doi.org/10.1016/j.jbiosc.2009.10.021

[81] Reis AB, Silva, WC, Souza, IF, Benassi VM, Roa JPB, Graziotti PH, Nelson DL. Determination of the biodegradability of chitosan utilizing the most probable number technique submetido ao periódico Acta Scientarium Biological Science. https://doi.org/10.4025/actascibiolsci.v42i1.52965

Received on 16-09-2020

DOI: https://doi.org/10.6000/1929-5995.2020.09.06

(C) 2020 Reis and Arrudas; Licensee Lifescience Global.

This is an open access article licensed under the terms of the Creative Commons Attribution Non-Commercial License (http://creativecommons.org/licenses/by-nc/3.0/) which permits unrestricted, non-commercial use, distribution and reproduction in any medium, provided the work is properly cited. 